\title{
Role of Bcl-xL/Beclin-1 in synergistic apoptotic effects of secretory TRAIL-armed adenovirus in combination with mitomycin $C$ and hyperthermia on colon cancer cells
}

\author{
Seog-Young Kim $\cdot$ Dae-Hee Lee $\cdot$ Xinxin Song $\cdot$ \\ David L. Bartlett • Yong Tae Kwon • \\ Yong J. Lee
}

Published online: 26 August 2014

(C) The Author(s) 2014. This article is published with open access at Springerlink.com

\begin{abstract}
In this study, we attempted to develop a multimodality approach using chemotherapeutic agent mitomycin C, biologic agent tumor necrosis factor-related apoptosis-inducing ligand (TRAIL/Apo-2L), and mild hyperthermia to treat colon cancer. For this study, human colon cancer LS174T, LS180, HCT116 and CX-1 cells were infected with secretory TRAIL-armed adenovirus (Ad.TRAIL) and treated with chemotherapeutic agent mitomycin $\mathrm{C}$ and hyperthermia. The combinatorial treatment caused a synergistic induction of apoptosis which was mediated through an increase in caspase activation. The combinational treatment promoted the JNK-Bcl-xL-Bak pathway which transmitted the synergistic effect through the mitochondria-dependent apoptotic pathway. JNK signaling led to Bcl-xL phosphorylation at serine 62, dissociation of Bak from Bcl-xL, oligomerization of Bak, alteration of mitochondrial membrane potential, and subsequent cytochrome $c$ release. Overexpression of
\end{abstract}

Seog-Young Kim and Dae-Hee Lee have contributed equally to this work.

S.-Y. Kim · D.-H. Lee · X. Song · D. L. Bartlett · Y. J. Lee ( $\varangle)$

Department of Surgery, School of Medicine, University of

Pittsburgh, Hillman Cancer Center, 5117 Centre Ave. Room

1.46C, Pittsburgh, PA 15213, USA

e-mail: leeyj@upmc.edu

Y. T. Kwon

Protein Metabolism Medical Research Center and Department of Biomedical Science, College of Medicine, Seoul National

University, Seoul 110-799, Korea

Y. J. Lee

Department of Pharmacology \& Chemical Biology, School of Medicine, University of Pittsburgh, Hillman Cancer Center,

5117 Centre Ave. Room 1.46C, Pittsburgh, PA 15213, USA dominant-negative mutant of $\mathrm{Bcl}-\mathrm{xL}$ (S62A), but not dominant-positive mutant of Bcl-xL (S62D), suppressed the synergistic death effect. Interestingly, Beclin-1 was dissociated from $\mathrm{Bcl}-\mathrm{xL}$ and overexpression of dominantnegative mutant of Bcl-xL (S62A), but not dominantpositive mutant of Bcl-xL (S62D), suppressed dissociation of Beclin-1 from Bcl-xL. A combinatorial treatment of mitomycin C, Ad.TRAIL and hyperthermia induced Beclin-1 cleavage, but the Beclin-1 cleavage was abolished in Beclin-1 double mutant (D133A/D146A) knock-in HCT116 cells, suppressing the apoptosis induced by the combination therapy. We believe that this study supports the application of the multimodality approach to colon cancer therapy.

Keywords Mitomycin C - Ad.TRAIL - Hyperthermia . Mitochondria-dependent pathway $\cdot$ Bcl-xL $\cdot$ Beclin-1

$\begin{array}{ll}\text { Abbreviations } \\ \text { Ad.TRAIL } & \text { TRAIL-armed adenovirus } \\ \text { APC } & \text { Allophycocyanin } \\ \text { ATM } & \text { Ataxia telangiectasia mutated } \\ \text { 53BP1 } & \text { p53-binding protein 1 } \\ \text { BAX } & \text { Bcl-2-associated X protein } \\ \text { Bcl-xL } & \text { B-cell lymphoma-extra large } \\ \text { BRCA1 } & \text { Early-onset familial breast and ovarian } \\ & \text { cancer } \\ \text { c-FLIP } & \text { Long form of cellular FLICE-inhibitory } \\ & \text { protein } \\ \text { Chk2 } & \text { Checkpoint kinase 2 } \\ \text { COX } & \text { Cyclooxygenase } \\ \text { CRE8 } & \text { Cre-expressing 293 cells } \\ \text { DMEM } & \text { Dulbecco's modified eagle medium } \\ \text { DR4 } & \text { Death receptor 4 } \\ \text { DR5 } & \text { Death receptor 5 }\end{array}$




$\begin{array}{ll}\text { DTT } & \text { Dithiothreitol } \\ \text { EDTA } & \text { Ethylenediaminetetraacetic acid } \\ \text { 5-FU } & \text { 5-fluorouracil } \\ \text { FADD } & \text { Fas-Associated protein with Death Domain } \\ \text { FBS } & \text { Fetal bovine serum } \\ \text { FLICE } & \begin{array}{l}\text { FADD-like interleukin-1 beta-converting } \\ \text { enzyme }\end{array} \\ \text { Flt3 } & \text { fms-related tyrosine kinase 3 } \\ \text { Flt3L } & \text { Ligand for Flt3 } \\ \text { HA } & \text { Hemagglutinin } \\ \text { HIPEC } & \text { Hyperthermic intraperitoneal chemotherapy } \\ \text { JNK } & \text { c-Jun NH2-terminal kinase } \\ \text { KI } & \text { Knock-in } \\ \text { MDC1 } & \text { Mediator of DNA damage checkpoint 1 } \\ \text { NBS1 } & \text { Nijmegen breakage syndrome } \\ \text { PARP } & \text { Poly (ADP-ribose) polymerase } \\ \text { PBS } & \text { Phosphate-buffered saline solution } \\ \text { PI } & \text { Propidium iodide } \\ \text { RPMI } & \text { Roswell Park Memorial Institute medium } \\ \text { SDS } & \text { Sodium dodecyl sulfate } \\ \text { PAGE } & \text { Polyacrylamide gel electrophoresis } \\ \text { BH3 } & \text { Bcl-2 homology domain 3 } \\ \text { TNF } & \text { Tumor necrosis factor } \\ \text { TRAIL } & \text { Tumor necrosis factor-related apoptosis- } \\ & \text { inducing ligand } \\ \text { WT } & \text { Wild-type }\end{array}$

\section{Introduction}

Colorectal cancer is the third leading cause of cancer-related mortality in the world. The main cause of death of patients with colorectal cancer is metastases [1]. In the last decade, the medical control of metastatic colorectal cancer has shown remarkable advances. For example, the addition of oxaliplatin and irinotecan to previously existing 5-fluorouracil (5-FU) and leucovorin-based therapies improved the overall median survival of 12 months [2], and with the addition of biological targeted therapies such as bevacizumab and cetuximab, the overall median survival rose to 20 months [3-8]. However, systemic chemotherapeutic strategies are currently used only as palliatives - they do not improve long-term survival rates. Therefore, new approaches are necessary to improve the overall median survival for metastatic colorectal cancers such as hepatic colorectal metastases and colorectal peritoneal carcinomatosis.

Current standard of care for hepatic colorectal metastases and colorectal peritoneal carcinomatosis is hyperthermic isolated hepatic perfusion (HIHP) therapy and hyperthermic intraperitoneal chemotherapy (HIPEC), respectively $[9,10]$. These therapies are combinatorial treatments of chemotherapeutic agents and mild hyperthermia. We hypothesize that a multimodality [chemotherapeutic agent mitomycin $\mathrm{C}$, biologic agent tumor necrosis factor-related apoptosis-inducing ligand (TRAIL/ Apo-2L), and mild hyperthermia] approach effectively enhances apoptotic death and improves the current standard of care to treat advanced colorectal metastases. To test the hypothesis, in this study, we focus on the effect of multimodality treatment on cell death in in vitro system.

Chemotherapy is the standard clinical treatment for human cancers. Chemotherapeutics can interact with DNA and activate several intracellular signal pathways including apoptosis [11]. Mitomycin C is an antibiotic which has been used as a chemotherapeutic agent in a variety of carcinogenic solid tumors including colon [12], breast [13], lung [14] and bladder [15]. Mitomycin C causes cross-links in the DNA molecules of the cells, leading to the formation of DNA interstrands and inhibiting DNA replication and transcription $[16,17]$. Previous reports suggest that mitomycin $C$ produces a consistent response when used as a single agent [18-21]. However, like many other chemotherapeutic agents, mitomycin $\mathrm{C}$ may induce resistance to chemotherapy and may target normal cells, thus causing unexpected side effects at therapeutic doses. On the other hand, since mitomycin $\mathrm{C}$ offers a suitably low toxicity and can be easily delivered to an outpatient, it seems a reasonable, costeffective candidate for combinational therapy of colorectal cancer, like irinotecan [22], capecitabine [23] or 5-FU [24].

TRAIL, a highly promising anticancer agent, is a cytokine of the TNF family which binds to the death receptors DR4 [25-27] and DR5 [28-30]. It has the unique ability to induce apoptosis in many transformed cancer cell lines, but not in normal tissue $[31,32]$. Previous studies suggest that TRAILinduced apoptosis can be enhanced by combinational therapy with several chemotherapeutic agents at non-toxic doses in cancer cells [33-38]. Nonetheless, the translation of TRAIL into the clinic has been confounded by its short half-life, inadequate delivery methods, and TRAIL-resistant cancer cell populations [39]. To solve these limitations, we attempt to develop a secretory TRAIL-armed adenoviral vector.

Hyperthermia has been explored as an anticancer agent for many decades and is often used with HIPEC. We previously reported that hyperthermia has a synergistic effect with TRAIL in causing cytotoxicity through the mitochondria-dependent pathway [40-43]. Several researchers also reported that hyperthermia acts synergistically with ionizing radiation [44-46], and with a number of chemotherapeutic agents [47-49]. We previously reported that hyperthermia triggered down-regulation of c-FLIP $_{\mathrm{L}}$ (long form of cellular FLICE-inhibitory protein), an anti-apoptotic molecule, in several colon cancer cells [50]. c-FLIP splice variants (long and short form) bind to FADD and/or caspase 8/10 and inhibit their activation [51-53]. 
In this study, we observed that a combinatorial treatment of mitomycin C, adenoviral TRAIL and hyperthermia effectively activates the mitochondrial-dependent apoptotic pathway by activating the JNK-Bcl-xL-Bak pathway, increasing Bak oligomerization, facilitating cytochrome $c$ release, promoting dissociation of Beclin-1 from $\mathrm{Bcl}-\mathrm{xL}$, and increasing Beclin-1 cleavage.

\section{Materials and methods}

Cell culture

The human colon adenocarcinoma line LS174T was kindly provided by Dr. HA Choudry (University of Pittsburgh Medical Center, Pittsburgh, PA, USA) and LS180 was purchased from the American Type Culture Collection (ATCC, Manassas, VA, USA). The human colorectal carcinoma HCT116 wild type was obtained from Dr. B Vogelstein (Johns Hopkins University) and CX-1 cell line was obtained from Dr. JM Jessup (National Cancer Institute). Cell lines were maintained in Dulbecco's Modified Eagle Medium (DMEM, Gibco, Gaithersburg, MD, USA), McCoy's 5A or RPMI 1640 supplemented with $10 \%$ fetal bovine serum (FBS, Atlanta Biological, Flowery Branch, GA, USA), $100 \mathrm{U} / \mathrm{mL}$ penicillin and $100 \mu \mathrm{g} / \mathrm{mL}$ streptomycin (Gibco) in a $5 \% \mathrm{CO}_{2}$ incubator. These adherent cells, except for LS180, were subcultured every 3-4 days by treatment with a trypsin-EDTA solution (Gibco). The LS180 cell line was cultured by following a procedure of ATCC subculturing.

\section{Reagents and antibodies}

Mitomycin $\mathrm{C}$ and anti-TRAIL antibody were obtained from Santa Cruz Biotechnology (Dallas, TX, USA). AntiPARP, anti-caspase 8/9/3, anti-cleaved caspase 9/3, antiphosphorylated (Thr183/Tyr185) JNK, anti-JNK, anti-Bcl$\mathrm{xL}$, anti-COX-IV and anti-human influenza hemagglutinin (HA) antibody were purchased from Cell Signaling (Danvers, MA, USA). Anti-phosphorylated Bcl-xL (S62) antibody was purchased from Millipore (Billerica, MA, USA) and anti-cytochrome $c$ antibody and anti-Beclin-1 were from BD Pharmigen (San Jose, CA, USA). Anti-actin antibody and other chemicals were purchased from Sigma (St. Louis, MO, USA).

Shuttle vector construction

pFETZ was kindly provided by Dr. Y He (Immunotherapy Center, Medical College of Georgia, GA, USA) [54]. This vector contains cDNA for the extracellular domain of Flt3L, a ligand for Flt3 tyrosine kinase receptor (a.a. 1-81), fused to a leucine zipper domain and the extracellular domain of TRAIL (a.a. 95-281) and expresses a secretable form of TRAIL fusion protein [55]. pAdlox-FETZ was made by inserting the SalI/BamHI fragment from pFETZ into SalI/BamHI-cut pAdlox shuttle vector. The complete shuttle vector was co-transfected into CRE8 cells with $\psi 5$ viral genomic DNA for homologous recombination as described below.

\section{Adenoviral vector construction}

Recombinant adenovirus was constructed by employing the Cre-lox recombination system [56]. The selective cell line CRE8 has a $\beta$-actin-based expression cassette driving a Cre recombinase gene with an $\mathrm{N}$-terminal nuclear localization signal stably integrated into 293 cells. Transfections were done by using Lipofectamine reagent (Invitrogen, Carlsbad, CA, USA). Cells were split into T25-flasks 1 day before transfection. For the production of recombinant adenovirus, $2 \mu \mathrm{g}$ of Adlox/FETZ and $2 \mu \mathrm{g}$ of $\psi 5$ viral genomic DNA were co-transfected into CRE8 cells in the presence of caspase inhibitor z-VAD-fmk $(20 \mu \mathrm{M})$. The recombinant adenoviruses were generated by intramolecular homologous recombination between the shuttle vector and $\psi 5$ viral DNA. The new virus had an intact packaging site and carried a recombinant gene. Plaques were harvested, analyzed and purified.

\section{Drug treatment}

Drug treatments were accomplished by aspirating the medium and replacing it with new medium containing drugs.

Hyperthermia treatment

Cells cultured in $35 \mathrm{~mm}$ or $100 \mathrm{~mm}$ dishes were sealed with parafilm and were placed a circulating water bath (Heto, Thomas Scientific, Denmark), which was maintained within $0.02{ }^{\circ} \mathrm{C}$ of the desired temperature.

\section{Survival assay}

One or 2 days prior to the experiment, human colorectal carcinoma LS174T cells were plated into six well plates. For trypan blue exclusion assay, trypsinized cells were pelleted and resuspended in $0.2 \mathrm{~mL}$ of medium, $0.5 \mathrm{~mL}$ of $0.4 \%$ trypan blue solution, and $0.3 \mathrm{~mL}$ of phosphate-buffered saline solution (PBS). The samples were mixed thoroughly, incubated at room temperature for $15 \mathrm{~min}$, and examined by automated cell counter (LUNA, Logos Biosystems, Annandale, VA, USA). At least 300 cells were counted for each survival determination. 
Protein extracts and polyacrylamide gel electrophoresis (PAGE)

Cells were scraped with $1 \times$ Laemmli lysis buffer [including 2.4 M glycerol, 0.14 M Tris (pH 6.8), $0.21 \mathrm{M}$ SDS, and $0.3 \mathrm{mM}$ bromophenol blue] and boiled for $3 \mathrm{~min}$. Protein concentrations were measured with BCA protein assay reagent (Pierce, Rockford, IL, USA). The samples were diluted with $1 \times$ lysis buffer containing $20 \mathrm{mM}$ dithiothreitol (DTT), and an equal amount of protein was loaded on 10-15\% SDS-polyacrylamide gels. SDS-PAGE analysis was performed using a Hoefer gel apparatus.

Immunoblot analysis

Proteins were separated by SDS-PAGE, electrophoretically transferred to nitrocellulose membranes and blocked with $5 \%$ skim milk in TBS-Tween $20(0.05 \%, \mathrm{v} / \mathrm{v})$ for $30 \mathrm{~min}$. The membrane was incubated with primary antibodies for $2 \mathrm{~h}$ at room temperature or overnight at $4{ }^{\circ} \mathrm{C}$. Horseradish peroxidase-conjugated anti-rabbit or anti-mouse $\operatorname{IgG}$ was used as the secondary antibody. Immunoreactive protein was visualized by the enhanced chemi-luminescence protocol (ECL, Amersham, Arlington Heights, IL, USA).

\section{Annexin V binding}

The translocation of phosphatidylserine, one of the markers of apoptosis, from the inner to the outer plasma membrane was detected by binding of allophycocyanin (APC)-conjugated Annexin V. LS174T cells were plated into plates, treated with drugs for $24 \mathrm{~h}$ and stained with mouse antihuman Annexin V antibody and propidium iodide (PI). The staining was terminated and cells were immediately analyzed by flow cytometry.

\section{JC-1 mitochondrial membrane potential assay}

After drug treatment, cells were stained using JC-1 mitochondrial membrane potential detection kit (Invitrogen) for $10 \mathrm{~min}$ and analyzed by flow cytometry. Fluorescence intensity was measured with the Accuri C6 flow cytometer (Accuri Cytometers, Inc., San Jose, CA, USA). Results were analyzed with VenturiOne software (Applied Cytometry, Inc., Plano, TX, USA).

Cytochrome $\mathrm{c}$ release assay

To determine the release of cytochrome $c$ from the mitochondria, LS174T cells growing in $100 \mathrm{~mm}$ dishes were used. After drug treatment, mitochondria and cytosolic fractions were prepared from treated cells by using a Mitochondrial Fractionation Kit (Active Motif, Carlsbad,
CA, USA) following company instructions and reagents included in the kit. Cytosolic fractions were subjected to SDS-PAGE and analyzed by immunoblotting using anticytochrome $c$ antibody. Equal loading of the mitochondrial pellets was confirmed with anti-COX IV antibody.

\section{Bak oligomerization}

After drug treatment, cells were collected and resuspended in homogenization buffer. The cell suspension was homogenized several times and centrifuged at $1,000 \times g$ for $10 \mathrm{~min}$ at $4{ }^{\circ} \mathrm{C}$ to obtain nuclear pellets. Supernatant was transferred to a new $1.5 \mathrm{~mL}$ tube and spun at $10,000 \times \mathrm{g}$ for $15 \mathrm{~min}$ at $4{ }^{\circ} \mathrm{C}$ to pellet the mitochondria. Isolated mitochondrial fractions and cytosolic fractions were crosslinked with $1 \mathrm{mmol} / \mathrm{L}$ dithiobis (Pierce) for $1 \mathrm{~h}$ at room temperature. After cross-linking, the mitochondria were pelleted and samples were subjected to SDS-PAGE under nondenaturing conditions followed by immunoblotting for Bak.

Stable transfection

Cells stably overexpressing HA-Bcl-xL wild-type (WT) or mutant types were prepared by transfecting CX-1 cells with human Bcl-xL tagged with HA epitope in pCDNA3.1 vector: HA-Bcl-xL WT, HA-Bcl-xL S62A (mutation of serine 62 to alanine), and HA-Bcl-xL S62D (mutation of serine 62 to aspartate; a kind gift from Dr. TC Chambers, University of Arkansas). Cells were maintained in $500 \mu \mathrm{g} /$ mL G418.

\section{Immunoprecipitation}

Briefly, cells were pelleted and lysed by CHAPS buffer with protease inhibitor cocktail. Cell lysates were completely disrupted by repeated aspiration through a 27 gauge needle. Cell debris was removed and protein concentration was determined by BCA Protein Assay Reagent. For immunoprecipitation, $500 \mu \mathrm{g}$ of lysate was incubated with $1 \mu \mathrm{g}$ of rabbit anti-Bcl-xL/anti-HA antibody or rabbit $\operatorname{IgG}$ at $4{ }^{\circ} \mathrm{C}$ overnight, followed by the addition of protein $\mathrm{G}$-agarose beads and rotation at $4{ }^{\circ} \mathrm{C}$ for $4 \mathrm{~h}$. Immunoprecipitates were collected by centrifugation and the pellet was dissolved in electrophoresis sample buffer for heat denaturation. The immune complexes were subjected to SDS-PAGE followed by immunoblot analysis.

Statistical analysis

Statistical analysis was carried out using GraphPad InStat 3 software (GraphPad Software, Inc., San Diego, CA, USA). 
A

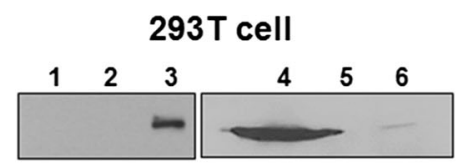

TRAIL
1: No transfection

2: pAdlox

3, 4: pAdloxFETZ

5: Untransfection medium $30 \mu \mathrm{l}$

6:Transfection medium $30 \mu \mathrm{l}$

\section{LS174T}

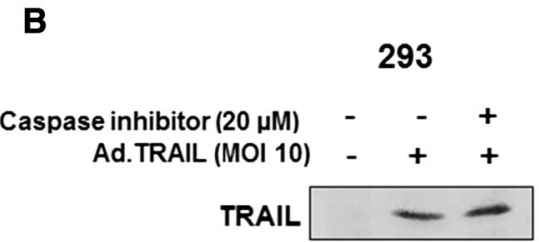

C

(MOI)
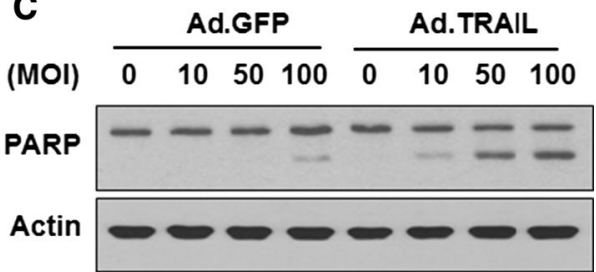

HCT116

\section{LS174T}

D

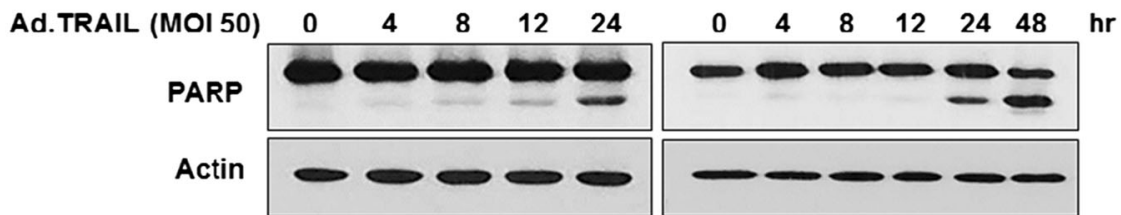

Fig. 1 Production of secretory TRAIL and its cytotoxicity. a 293 cells were non-transfected (lane 1), or transfected with $4 \mu \mathrm{g}$ pAdlox empty vector (lane 2) or pAdlox-FETZ vector (lane 3,4) and then incubated for $48 \mathrm{~h}$. After incubation, $30 \mu \mathrm{g}$ of cell lysate protein (lane $1,2,3$, and 4 ) or $30 \mu \mathrm{L}$ of cell culture medium (lane 5,6 ) were immunoblotted with anti-TRAIL antibody. b 293 cells were infected with Ad.TRAIL (MOI 10) in the presence/absence of caspase

Significance was set at values of $*(p<0.05), * *(p<$ $0.01)$, or $* * *(p<0.001)$.

\section{Results}

Characterization of a secretory TRAIL-armed adenoviral vector

We constructed pAdlox-FETZ shuttle vector which has a CMV promoter-driven secretory human Flt3 ligand-isoleucine zipper-human TRAIL fusion protein gene. This plasmid encoded the secretable form of chimeric TRAIL proteins which were detected in Fig. 1a. Next, we constructed a secretory TRAIL-armed adenoviral vector (Ad.TRAIL) and characterized the vector. Data from Fig. $1 \mathrm{~b}$ shows an expression of TRAIL in Ad.TRAIL infected 293 cells in the absence/presence of caspase inhibitor z-VAD-fmk, which was added to prevent TRAILinduced apoptosis. Unlike most cancer cell lines, immortalized normal human embryonic kidney 293 cells were resistant to TRAIL. To examine an apoptotic capacity of Ad.TRAIL, human colon adenocarcinoma LS174T cells were infected with various multiplicity of infection (MOI) of Ad.TRAIL and its control adenoviral construct encoding inhibitor $(20 \mu \mathrm{M})$. Cell lysates were prepared in lysis buffer and immunoblotted with anti-TRAIL. c LS174T cells were infected by various MOI of Ad.TRAIL or Ad.GFP for $24 \mathrm{~h}$ and harvested. Cell lysates were immunoblotted with anti-PARP antibody. d HCT116 and LS174T cells were infected with Ad.TRAIL (MOI 50) and harvested at various time points. Cell lysates were immunoblotted with antiPARP antibody. Actin was used as an internal standard

green fluorescent protein (Ad.GFP). As shown in Fig. 1c, Ad.TRAIL induced PARP cleavage, the hallmark feature of apoptosis. TRAIL-induced PARP cleavage was dependent upon MOI. Unlike Ad.TRAIL, Ad.GFP induced minimal apoptosis only at MOI of 100 . Next, we investigated the kinetics of apoptosis after Ad.TRAIL infection in human colorectal carcinoma HCT116 and LS174T cells. Figure 1d shows that PARP cleavage occurred $24 \mathrm{~h}$ after infection in both cell lines.

Synergistic induction of apoptosis by Ad.TRAIL in combination with mitomycin $\mathrm{C}$ and hyperthermia

To investigate the effect on cell viability of the application of Ad.TRAIL in combination with mitomycin $\mathrm{C}$ and hyperthermia, LS174T cells were infected with Ad.TRAIL (MOI 25) and treated with $5 \mu \mathrm{g} / \mathrm{mL}$ mitomycin $\mathrm{C}$ for $24 \mathrm{~h}$. After treatment, the cells were heated at $42{ }^{\circ} \mathrm{C}$ for $1 \mathrm{~h}$ and incubated at $37{ }^{\circ} \mathrm{C}$ for $3 \mathrm{~h}$ and then cell viability was determined by trypan blue dye exclusion assay. As shown in Fig. 2a, synergistic cytotoxic effect was observed in Ad.TRAIL + mitomycin C or Ad.TRAIL + mitomycin $\mathrm{C}+$ hyperthermia compared with any single treatment $(p<0.05)$. We further investigated whether the combinatorial treatment-induced cytotoxicity was associated with 


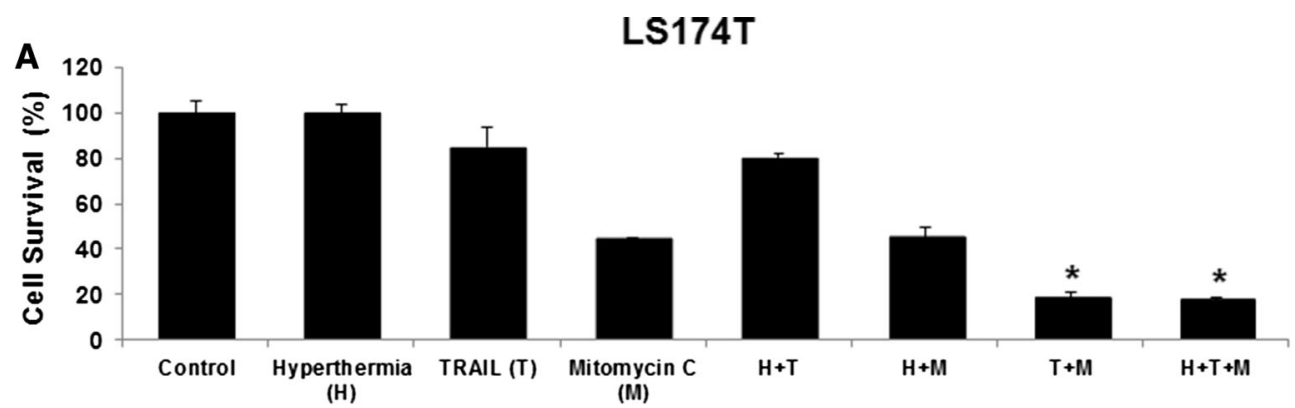

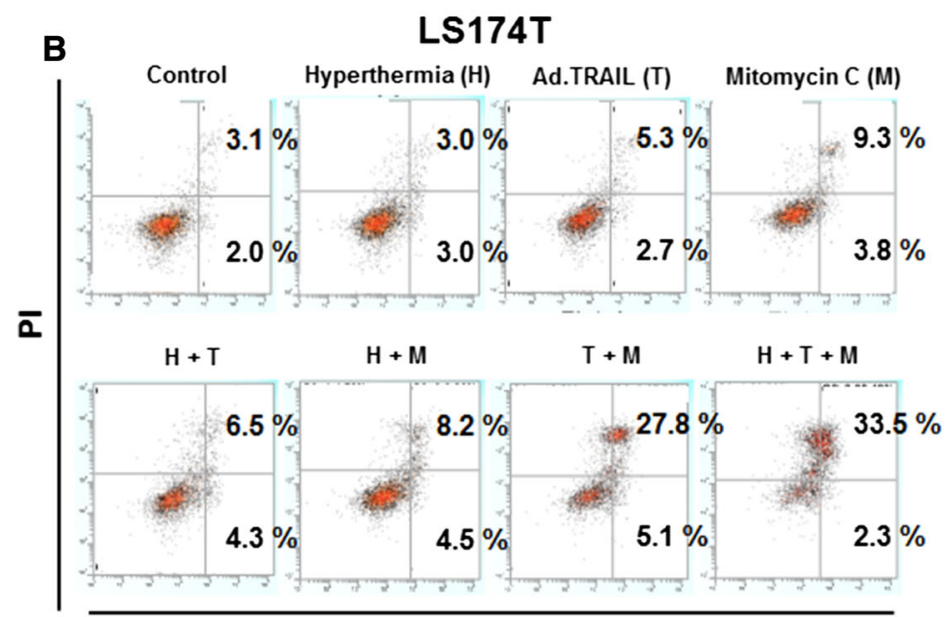

Annexin V

Fig. 2 Synergistic induction of cytotoxicity by treatment with Ad.TRAIL in combination with mitomycin $\mathrm{C}$ and hyperthermia in LS174T cells. LS174T cells were treated with Ad.TRAIL (MOI 25) or/and mitomycin $\mathrm{C}(5 \mu \mathrm{g} / \mathrm{mL})$ for $24 \mathrm{~h}$ and exposed to normothermia $\left(37^{\circ} \mathrm{C}\right)$ or hyperthermia $\left(42{ }^{\circ} \mathrm{C}\right)$ for $1 \mathrm{~h}$, and then incubated for $3 \mathrm{~h}$ at $37^{\circ} \mathrm{C}$. a Cell survival was analyzed by the trypan blue dye exclusion

apoptosis. Data from the flow cytometry assay demonstrate that the combinatorial treatment-induced cytotoxicity was associated with apoptosis (Figs. 2b, c); apoptotic death cells were observed in the lower right quadrant (early apoptotic death) and the upper right quadrant (late apoptotic death) of the plots. The results from Figs. 2b, c clearly demonstrate that apoptosis was time-dependent during combined treatment. Figures $2 b$, c clearly show that treatment with Ad.TRAIL in combination with mitomycin $\mathrm{C}$ and hyperthermia enhanced synergistic induction of apoptotic death. These synergistic effects were due to an increased activation (cleavage) of caspase 8/9/3 and thus, the hallmark feature of apoptosis, PARP cleavage (Fig. 3a). Similar results were observed in LS180, CX-1 and HCT116 cell lines (Figs. 3b, c, d). These results indicate that synergistic induction of apoptosis by combinatorial treatment with mitomycin C/Ad.TRAIL/hyperthermia is mediated through an increase in caspase activation.

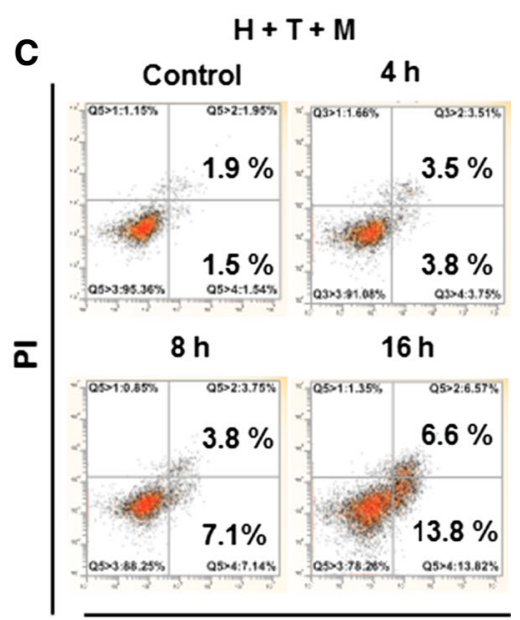

Annexin V

assay. b Cells were stained with fluorescein isothiocyanate (FITC)Annexin $\mathrm{V}$ and propidium iodide (PI). c Cells were treated with Ad.TRAIL (MOI 25) and mitomycin C (5 $\mu \mathrm{g} / \mathrm{mL})$ for 4,8 , and $16 \mathrm{~h}$ and exposed to hyperthermia $\left(42^{\circ} \mathrm{C}\right)$ for $1 \mathrm{~h}$, and then incubated for $3 \mathrm{~h}$ at $37^{\circ} \mathrm{C}$. Apoptosis was detected by the flow-cytometric assay

Role of the JNK-Bcl-xL-Bak pathway in the combinatorial treatment-induced apoptosis

We previously reported that the JNK-Bcl-xL pathway plays an important role in the synergistic effect on apoptosis of treatment with multiple cytotoxic agents [43, 57]. This possibility was examined during treatment with mitomycin C/Ad.TRAIL/hyperthermia. Phosphorylation of JNK and Bcl-xL was observed during treatment with mitomycin C/Ad.TRAIL/hyperthermia in LS174T cells (Fig. 4a). Even with treatment with only mitomycin $\mathrm{C}$, phosphorylation of $\mathrm{JNK}$ and $\mathrm{Bcl}-\mathrm{xL}$ was detected. Moreover, an increase in phosphorylation was observed during combinatorial therapy. Data from immunoprecipitation assay show that the combinatorial treatment induced the dissociation of Bak from Bcl-xL (Fig. 4b). We previously reported that phosphorylation of $\mathrm{Bcl}-\mathrm{xL}$ alters the interactions between Bcl-xL and Bax and then leads to Bax oligomerization [43]. Since the presence of Bax was not 


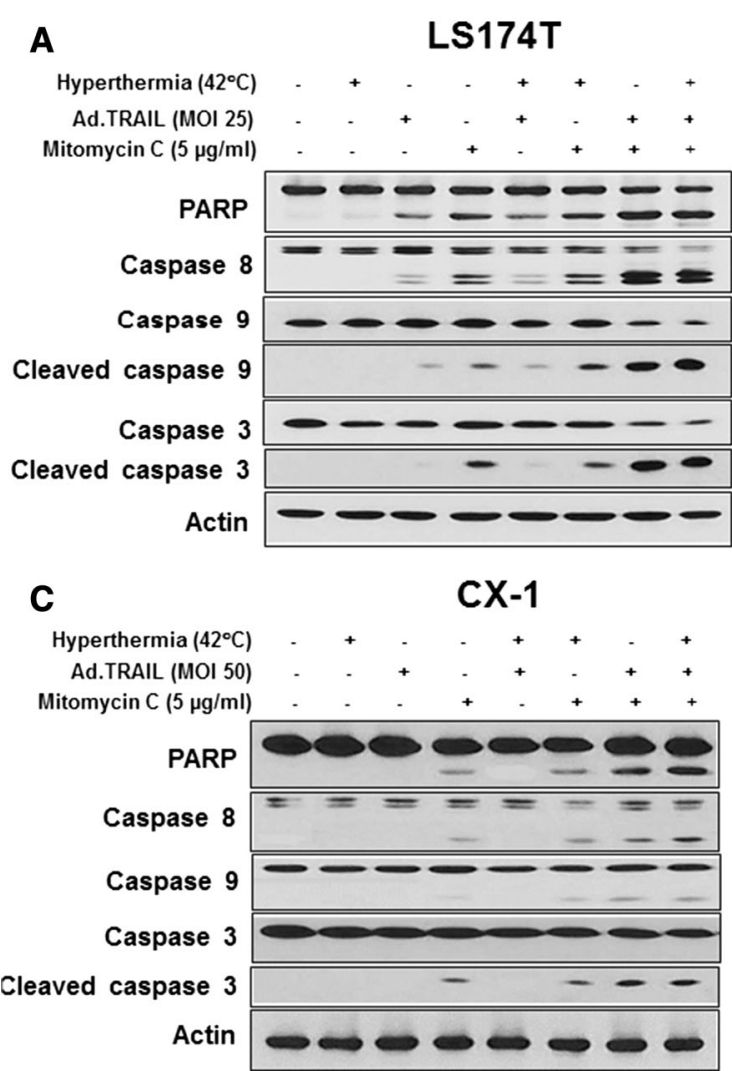

Fig. 3 Synergistic induction of apoptosis by treatment with Ad.TRAIL in combination with mitomycin $\mathrm{C}$ and hyperthermia in colon cancer cells. LS174T (a), LS180 (b), CX-1 (c) and HCT116 (d) cells were treated with Ad.TRAIL (MOI 25 or 50) or/and mitomycin $\mathrm{C}$ ( 3.5 or $5 \mu \mathrm{g} / \mathrm{mL}$ ) for $24 \mathrm{~h}$ and exposed to normothermia

detected in LS174T cells (data not shown), we examined Bak oligomerization. Bak oligomerization occurred during treatment with Ad.TRAIL in combination with mitomycin $\mathrm{C}$ with/without hyperthermia (Fig. 4c). Oligomerized Bak may bind to the mitochondria, altering mitochondrial membrane potential (Fig. 4d) and causing a cytochrome c release (Fig. 4e).

Alteration of interactions between Bcl-xL and Beclin-1 and cleavage of Beclin-1 during the combinatorial treatment

To examine whether phosphorylation of the $\mathrm{S} 62$ residue on Bcl-xL is important for apoptosis, CX-1 cells were stably transfected with plasmid containing HA-Bcl-xL WT, phosphor-defective HA-Bcl-xL S62A or phosphor-mimic HA-Bcl-xL S62D. Figure 5a shows that HA-Bcl-xL S62A, but not HA-Bcl-xL WT and HA-Bcl-xL S62D, inhibited apoptosis. These results suggest that the phosphorylation of Bcl-xL plays an important role in the combinatorial treatment-induced apoptosis. We previously reported that phosphorylation of Bcl-xL affects interaction between Bcl-
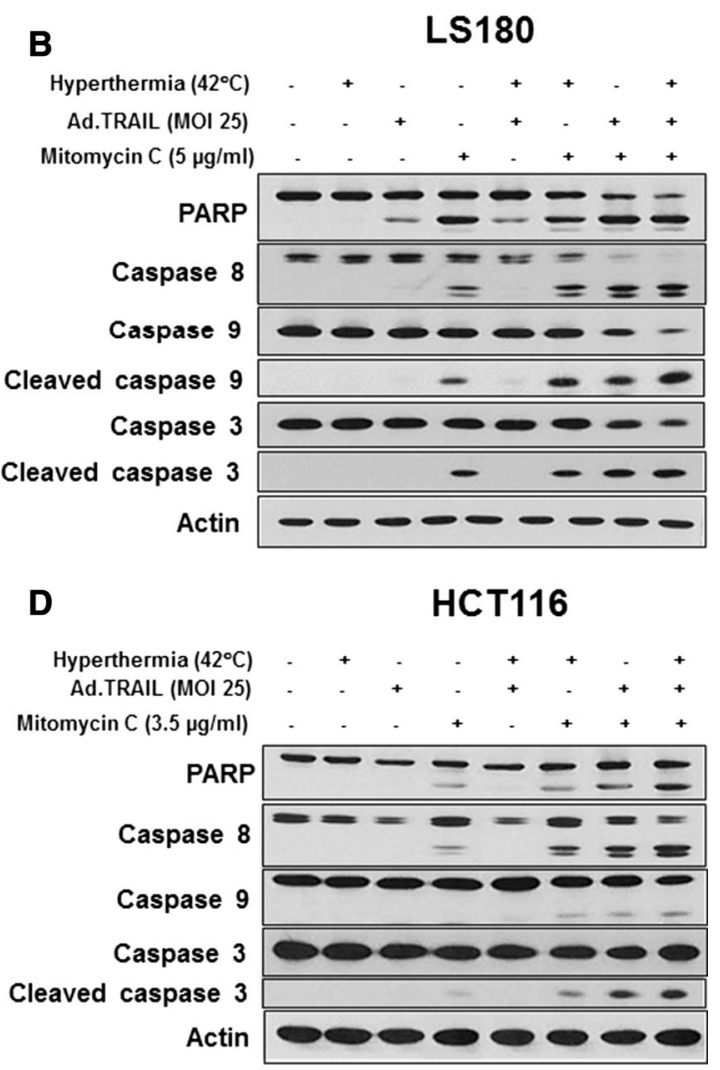

$\left(37^{\circ} \mathrm{C}\right)$ or hyperthermia $\left(42^{\circ} \mathrm{C}\right)$ for $1 \mathrm{~h}$, and then incubated for $3 \mathrm{~h}$ at $37{ }^{\circ} \mathrm{C}$. After treatment, the cleavage of caspase $8 / 9 / 3$ or PARP was detected by immunoblotting. Actin was used to confirm the equal amount of proteins loaded in each lane

$\mathrm{xL}$ and Beclin-1, causing dissociation of Beclin-1 from Bcl-xL [57]. Data from immunoprecipitation assay show that overexpression of dominant-negative mutant type of Bcl-xL S62A, but not wild type Bcl-xL WT or dominantpositive mutant type of Bcl-xL S62D, suppressed the dissociation of Beclin-1 from Bcl-xL (Fig. 5b). Several researchers reported that Beclin-1 has two cleavage sites at D133 and D146 residues [58] and that Beclin-1 is cleaved by caspase 8 , and C-terminal fragment of Beclin-1 localizes at the mitochondria and then induces cytochrome $c$ release $[58,59]$. Figure $6 a$ shows that the combinatorial treatment enhanced Beclin-1 cleavage. On Fig. 6b, data from Beclin-1 double mutant (D133A/D146A) knock-in HCT116 cells show suppression of cleavage of PARP and caspase 8/9/3 (apoptosis). Beclin-1, a mammalian homolog of yeast autophagy-related protein 6 (Atg6), functions in autophagy by initiating autophagosome formation [60]. However, it has been suggested that crosstalk between apoptosis and autophagy is associated with caspase-mediated cleavage of Beclin-1 which destroys its pro-autophagic activity and can then amplify mitrochondrion-mediated apoptosis through the cleaved C-terminal fragment [58]. 
A

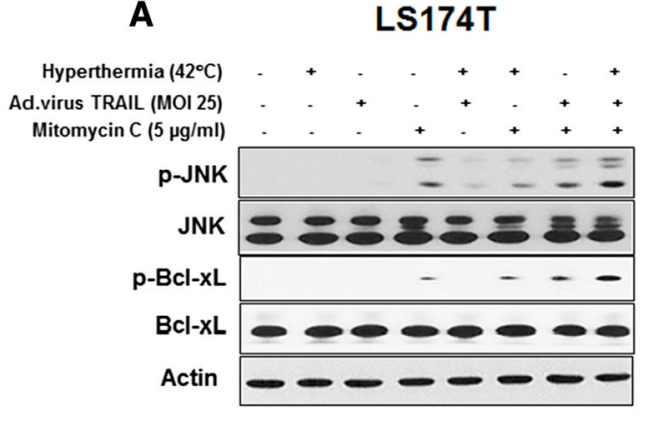

C

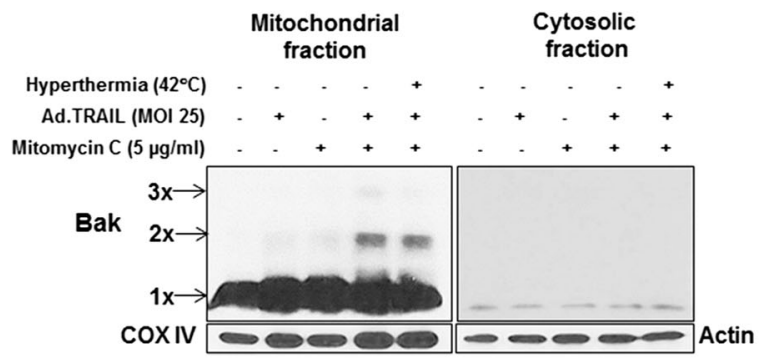

\section{B}

Hyperthermia $\left(42^{\circ} \mathrm{C}\right)$ Ad.TRAIL (MOI 25)

Mitomycin C (5 $\mu \mathrm{g} / \mathrm{ml})$
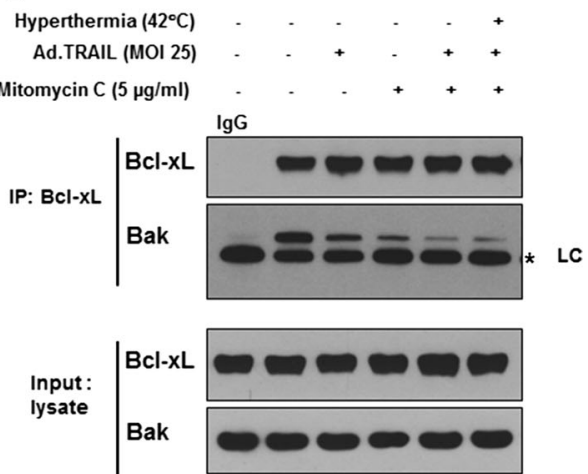

LS174T

D

\section{LS174T}

Hvperthermia $\left(42^{\circ} \mathrm{C}\right)$

Ad.TRAIL (MOI 25)

Mitomycin C (5 $\mu \mathrm{g} / \mathrm{ml})$
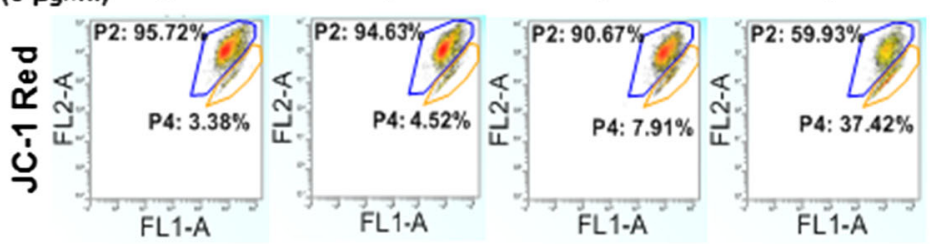

Hyperthermia $\left(42^{\circ} \mathrm{C}\right)$

Ad.TRAIL (MOI 25)

Mitomycin C $(5 \mu \mathrm{g} / \mathrm{ml})$
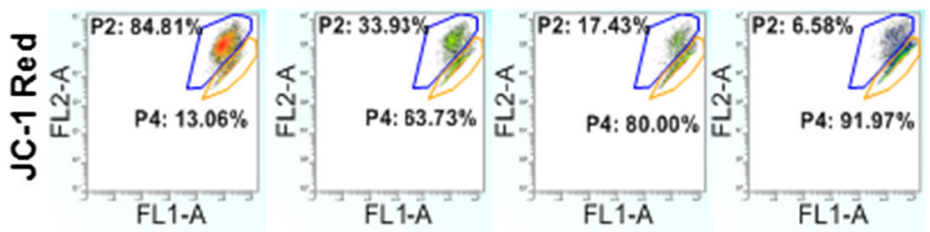

\section{JC-1 Green}

E

\section{LS174T}

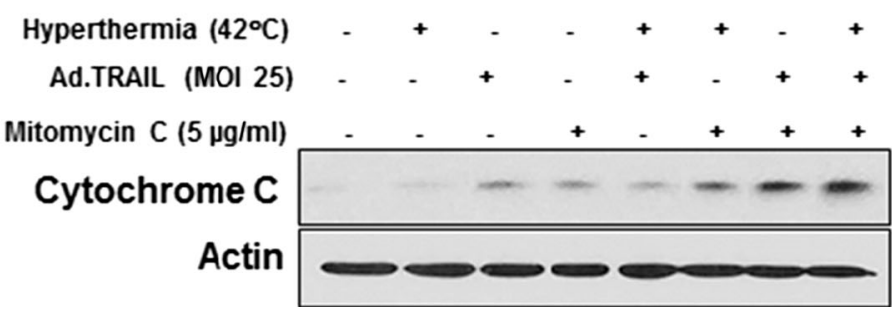


4Fig. 4 Ad.TRAIL in combination with mitomycin $\mathrm{C}$ and hyperthermia-induced activation of the JNK-Bcl-xL pathway, Bak oligomerization, mitochondrial membrane potential change and cytochrome $c$ release. LS174T cells were treated with Ad.TRAIL (MOI 25) or/and mitomycin $\mathrm{C}(5 \mu \mathrm{g} / \mathrm{mL})$ for $24 \mathrm{~h}$ and exposed to normothermia $\left(37^{\circ} \mathrm{C}\right)$ or hyperthermia $\left(42{ }^{\circ} \mathrm{C}\right)$ for $1 \mathrm{~h}$, and then incubated for $3 \mathrm{~h}$ at $37^{\circ} \mathrm{C}$. a After treatment, cell lysates containing equal amounts of protein were separated by SDS-PAGE and immunoblotted with antiphospho-JNK, anti-JNK, anti-phospho Bcl-xL or anti-Bcl-xL antibody. b Cell lysates were immunoprecipitated with anti-Bcl-xL antibody or $\operatorname{IgG}$ and immunoblotted with anti-Bak antibody. The presence of Bcl-xL and Bak in the lysates was examined. Asterisk (*) is IgG light chain (LC). c Mitochondrial and cytosolic fractions were isolated and were cross-linked with 1 M DSP (dithiobis, succinimidyl propionate) for $30 \mathrm{~min}$ and then subjected to immunoblotting with anti-Bak antibody. Bak monomer $(\times 1)$ and multimer $(\times 2, \times 3)$ are indicated. COX IV and actin were shown as an internal standard of mitochondrial fraction and cytosolic fraction, respectively. d Cells were stained with JC-1 and then analyzed by flow cytometry. e Cytochrome $c$ release into cytosol was determined by immunoblotting for cytochrome $c$ in the cytosolic fraction. Actin was used to confirm the equal amount of proteins loaded

Our data suggest that the combinatorial treatment-induced synergistic apoptotic death is mediated through Beclin-1 cleavage.

\section{Discussion}

Several conclusions can be drawn upon consideration of the data presented here. First, a combinatorial treatment of Ad.TRAIL, mitomycin $\mathrm{C}$ and hyperthermia synergistically induces apoptosis. Second, the JNK-Bcl-xL-Bak pathway plays an important role in the apoptosis through activating the mitochondria-dependent pathway. Third, a combinatorial treatment of Ad.TRAIL, mitomycin $\mathrm{C}$ and hyperthermia induces dissociation of Beclin-1 from Bcl-xL and promotes Beclin-1 cleavage which results in enhancement of apoptosis.

The DNA damage surveillance network may orchestrate cellular responses to mitomycin C-induced DNA damage through the recruitment of DNA damage sensing molecules, transducer and effector proteins [61]. Ataxia telangiectasia mutated (ATM) and Nijmegen breakage syndrome (NBS1) cooperatively sense DNA damage and post-translationally modify transducers such as BRCA1 (early-onset familial breast and ovarian cancer), MDC1 (mediator of DNA damage checkpoint 1), 53BP1 (p53binding protein 1), and c-Abl [62, 63]. These modified transducer proteins amplify and transduce the signals to downstream effectors such as H2AX, p53, Chk2 and JNK [64-72]. It is possible that mitomycin C-activated JNK is mediated through the ATM-c-Abl signal transduction pathway. This possibility needs to be further investigated.

We previously reported that Bcl-xL undergoes phosphorylation in response to treatment with oxaliplatin,

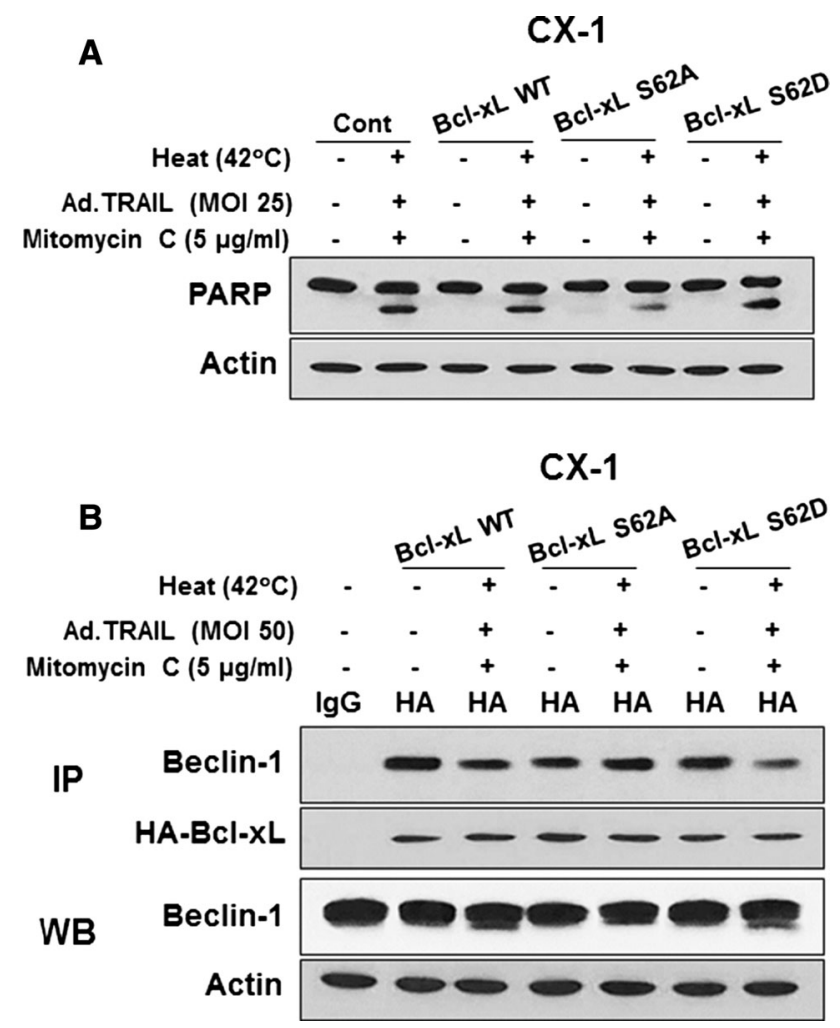

Fig. 5 Role of Bcl-xL in apoptosis. CX-1 cells were stably transfected with HA-Bcl-xL WT, HA-Bcl-xL S62A or HA-Bcl-xL S62D plasmid and then treated with Ad.TRAIL (MOI 25) and/or mitomycin $\mathrm{C}(5 \mu \mathrm{g} / \mathrm{mL})$ for $24 \mathrm{~h}$ and exposed to normothermia $\left(37^{\circ} \mathrm{C}\right)$ or hyperthermia $\left(42^{\circ} \mathrm{C}\right)$ for $1 \mathrm{~h}$, and then incubated for $3 \mathrm{~h}$ at $37^{\circ} \mathrm{C}$. a After treatment, lysates containing equal amounts of protein were separated by SDS-PAGE and PARP cleavage was detected by immunoblotting. Actin was used as an internal standard. b Cell lysates were immunoprecipitated with anti-HA antibody or mock antibody (IgG) and immunoblotted with anti-Beclin-1 or anti-HA antibody (upper panels). The presence of Beclin-1 and actin in the lysates was examined (lower panels)

TRAIL/mapatumumab and hyperthermia $[42,43,57,73-$ 75]. Bcl-xL phosphorylation requires activated JNK, which can recognize a proline residue on the carboxyl side of the phospho-acceptor [76]. Some studies reported Bcl-xL phosphorylation to occur on serine 62 , while others reported it to occur on threonines 47 and 115 [77, 78]. This study with site-directed mutagenesis at Ser-62 showed that cells expressing a validated phospho-defective Bcl-xL mutant are resistant to the combinatorial treatment of Ad.TRAIL, mitomycin $\mathrm{C}$ and hyperthermia-induced apoptosis, whereas cells expressing a phospho-mimic Bcl$\mathrm{xL}$ are sensitive to the combinatorial treatment-induced apoptosis, indicating that phosphorylation at Ser-62 is a key regulatory mechanism for antagonizing anti-apoptotic function in the combinatorial treatment.

Previous studies have shown that JNK1-mediated phosphorylation of Bcl-2 at residues T69, S70, and S87 is 


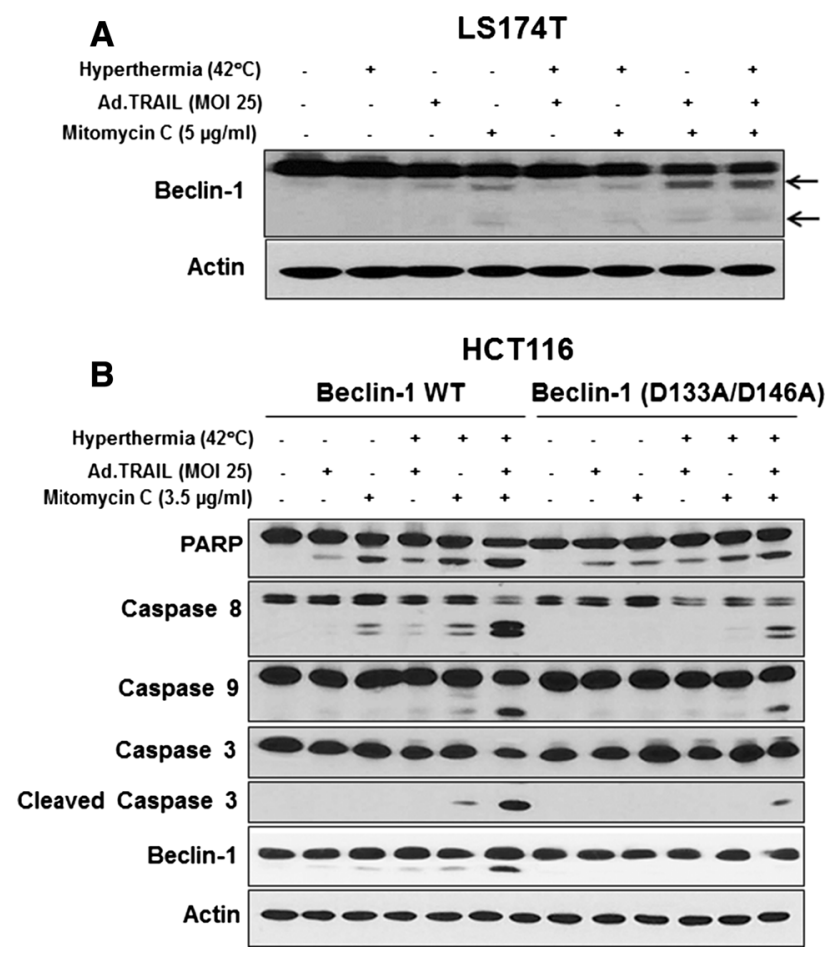

Fig. 6 Role of Beclin-1 in Ad.TRAIL in combination with mitomycin C and hyperthermia-induced cell death. LS174T, HCT116 and HCT116 Beclin-1 knock-in (D133A/D146A) cells were treated with Ad.TRAIL (MOI 25) or/and mitomycin C $(3.5$ or $5 \mu \mathrm{g} / \mathrm{mL})$ for $24 \mathrm{~h}$ and exposed to normothermia $\left(37^{\circ} \mathrm{C}\right)$ or hyperthermia $\left(42{ }^{\circ} \mathrm{C}\right)$ for $1 \mathrm{~h}$, and then incubated for $3 \mathrm{~h}$ at $37{ }^{\circ} \mathrm{C}$. a LS174T cell lysates were immunoblotted by Beclin-1 antibody. Arrows indicate cleaved Beclin-1. b Parental HCT116 (HCT116 WT) and HCT116 D133A/ D146A cell lysates were immunoblotted with anti-PARP, anti-caspase $8 / 9 / 3$, or anti-Beclin-1 antibody. Actin was shown as an internal standard

required for dissociation of Bcl-2 from Beclin-1 and autophagy activation [79]. Unlike Bcl-2, data from Fig. 5b suggests that for Bcl-xL, phosphorylation only at residue S62 may be sufficient for Bcl-xL dissociation from Beclin1. It was reported that D133 and D146 of Beclin-1 are cleaved by caspase 8 during apoptosis [58, 59]. Caspase 8-mediated cleavage of Beclin-1 inactivates Beclin-1induced autophagy and enhances apoptosis by promoting the release of proapoptotic factors from mitochondria [58, 59]. Studies with the caspase 8-resistant Beclin-1 knockin cell line clearly demonstrate that the combinatorial treatment-induced Beclin-1 cleavage and apoptosis were reduced (Fig. 6b), and Beclin-1's autophagy-promoting function was restored (data not shown) in Beclin-1 KI HCT116 cells.

We reported that hyperthermia has a synergistic effect with TRAIL in causing apoptosis [40-42]. We also reported that hyperthermia triggers down-regulation of c-FLIP ${ }_{\mathrm{L}}$ (long form of cellular FLICE-inhibitory protein), an anti-apoptotic molecule, through ubquitination in several colon cancer cell lines [50]. It has been found that c-FLIP splice variants (long and short form) bind to FADD and/or caspase 8/10 and inhibit their activation [51-53]. Thus, down-regulation of c-FLIP ${ }_{L}$ is probably responsible for hyperthermia-enhanced TRAIL cytotoxicity. Interestingly, long-term pretreatment with TRAIL by expressing TRAIL from Ad.TRAIL showed a minimal synergistic effect with hyperthermia, even though down-regulation of c-FLIP ${ }_{\mathrm{L}}$ was observed (data not shown). This may be due to the activation of TRAIL-associated death signals prior to hyperthermia. This possibility needs to be further studied.

Our data illustrate that a combinatorial treatment of Ad.TRAIL, mitomycin $\mathrm{C}$ and mild hyperthermia synergistically induces apoptosis and effectively activates the mitochondria-dependent apoptotic pathway by activating the JNK-Bcl-xL-Bak pathway. Moreover, our data suggest that Beclin-1 is dissociated from phosphorylated Bcl-xL and cleaved during treatment with Ad.TRAIL, mitomycin $\mathrm{C}$ and hyperthermia. The cleavage of Beclin-1 promoted the combinatorial treatment-induced apoptotic death. The studies presented here further elucidate a crosstalk between the JNK-Bcl-xL-Bak pathway and the Bcl-xL/Beclin-1mediated pathway during treatment with Ad.TRAIL, mitomycin $\mathrm{C}$ and hyperthermia. A greater understanding of these interactions may be critical for enhancing the combinatorial treatment.

Acknowledgments This work was supported by NCI Grant R01CA140554 (Y.J.L.) and the Basic Science Research Program of the National Research Foundation of Korea funded by the Ministry of Science, ICT and Future Planning (NRF-2013R1A2A2A01014170, Y.T.K.). This project used the UPCI Core Facility and was supported in part by award P30CA047904.

Conflict of interest The authors declare no competing financial interests.

Open Access This article is distributed under the terms of the Creative Commons Attribution License which permits any use, distribution, and reproduction in any medium, provided the original author(s) and the source are credited.

\section{References}

1. Chua TC, Esquivel J, Pelz JO, Morris DL (2013) Summary of current therapeutic options for peritoneal metastases from colorectal cancer. J Surg Oncol 107:566-573

2. Saltz LB, Cox JV, Blanke C, Rosen LS, Fehrenbacher L, Moore MJ, Maroun JA, Ackland SP, Locker PK, Pirotta N, Elfring GL, Miller LL (2000) Irinotecan plus fluorouracil and leucovorin for metastatic colorectal cancer. Irinotecan Study Group. N Eng J Med 343:905-914

3. Hurwitz H, Fehrenbacher L, Novotny W, Cartwright T, Hainsworth J, Heim W, Berlin J, Baron A, Griffing S, Holmgren E, Ferrara N, Fyfe G, Rogers B, Ross R, Kabbinavar F (2004) Bevacizumab plus irinotecan, fluorouracil, and leucovorin for metastatic colorectal cancer. N Engl J Med 350:2335-2342 
4. Colucci G, Gebbia V, Paoletti G, Giuliani F, Caruso M, Gebbia N, Cartenì G, Agostara B, Pezzella G, Manzione L, Borsellino N, Misino A, Romito S, Durini E, Cordio S, Di Seri M, Lopez M, Maiello E, Montemurro S, Cramarossa A, Lorusso V, Di Bisceglie M, Chiarenza M, Valerio MR, Guida T, Leonardi V, Pisconti S, Rosati G, Carrozza F, Nettis G, Valdesi M, Filippelli G, Fortunato S, Mancarella S, Brunetti C (2005) Phase III randomized trial of FOLFIRI versus FOLFOX4 in the treatment of advanced colorectal cancer: a multicenter study of the Gruppo Oncologico Dell'Italia Meridionale. J Clin Oncol 23:4866-4875

5. Cassidy J, Clarke S, Díaz-Rubio E, Scheithauer W, Figer A, Wong R, Koski S, Lichinitser M, Yang TS, Rivera F, Couture F, Sirzén F, Saltz L (2008) Randomized phase III study of capecitabine plus oxaliplatin compared with fluorouracil/folinic acid plus oxaliplatin as first-line therapy for metastatic colorectal cancer. J Clin Oncol 26:2006-2012

6. Porschen R, Arkenau HT, Kubicka S, Greil R, Seufferlein T, Freier W, Kretzschmar A, Graeven U, Grothey A, Hinke A, Schmiegel W, Schmoll HJ (2007) Phase III study of capecitabine plus oxaliplatin compared with fluorouracil and leucovorin plus oxaliplatin in metastatic colorectal cancer: a final report of the AIO Colorectal Study Group. J Clin Oncol 25:4217-4223

7. Saltz LB, Clarke S, Díaz-Rubio E, Scheithauer W, Figer A, Wong R, Koski S, Lichinitser M, Yang TS, Rivera F, Couture F, Sirzén F, Cassidy J (2008) Bevacizumab in combination with oxaliplatinbased chemotherapy as first-line therapy in metastatic colorectal cancer: a randomized phase III study. J Clin Oncol 26:2013-2019

8. Falcone A, Ricci S, Brunetti I, Pfanner E, Allegrini G, Barbara C, Crinò L, Benedetti G, Evangelista W, Fanchini L, Cortesi E, Picone V, Vitello S, Chiara S, Granetto C, Porcile G, Fioretto L, Orlandini C, Andreuccetti M, Masi G (2007) Phase III trial of infusional fluorouracil, leucovorin, oxaliplatin, and irinotecan (FOLFOXIRI) compared with infusional fluorouracil, leucovorin, and irinotecan (FOLFIRI) as first-line treatment for metastatic colorectal cancer: the Gruppo Oncologico Nord Ovest. J Clin Oncol 25:1670-1676

9. Zeh HJ 3rd, Brown CK, Holtzman MP, Egorin MJ, Holleran JL, Potter DM, Bartlett DL (2009) A phase I study of hyperthermic isolated hepatic perfusion with oxaliplatin in the treatment of unresectable liver metastases from colorectal cancer. Ann Surg Oncol 16:385-394

10. Ceelen WP (2013) Current management of peritoneal carcinomatosis from colorectal cancer. Minerva Chir 68:77-86

11. Siddik ZH (2003) Cisplatin: mode of cytotoxic action and molecular basis of resistance. Oncogene 22:7265-7279

12. Chong G, Dickson JL, Cunningham D, Norman AR, Rao S, Hill ME, Price TJ, Oates J, Tebbutt N (2005) Capecitabine and mitomycin $\mathrm{C}$ as third-line therapy for patients with metastatic colorectal cancer resistant to fluorouracil and irinotecan. $\mathrm{Br} \mathrm{J}$ Cancer 93:510-514

13. Tanabe M, Ito Y, Tokudome N, Sugihara T, Miura H, Takahashi S, Seto Y, Iwase T, Hatake K (2009) Possible use of combination chemotherapy with mitomycin $\mathrm{C}$ and methotrexate for metastatic breast cancer pretreated with anthracycline and taxanes. Breast Cancer 16:301-306

14. Berghmans T, Gourcerol D, Lafitte JJ, Kotsori K, Paesmans M, Scherpereel A, Leclercq N, Sculier JP (2008) Mitomycin plus vinorelbine salvage chemotherapy in non-small cell lung cancer: a prospective study. Lung Cancer 61:378-384

15. Horvath A, Mostafid H (2009) Therapeutic options in the management of intermediate-risk nonmuscle-invasive bladder cancer. BJU Int 103:726-729

16. Iyer VN, Szybalski W (1964) Mitomycins and porfiromycin: chemical mechanism of activation and cross-linking of DNA. Science 145:55-58
17. Iyer VN, Szybalski W (1963) A molecular mechanism of mitomycin action: linking of complementary DNA strands. Proc Natl Acad Sci USA 50:355-362

18. Carter SK, Comis RL (1975) The integration of chemotherapy into a combined modality approach for cancer treatment IV: pancreatic adenocarcinoma. Cancer Treat Rev 2:193-214

19. Whittington RM, Close HP (1970) Clinical experience with mitomycin C. Cancer Chemother Rep 54:195-198

20. Carter SK (1968) Mitomycin C-clinical brochure. Cancer Chemother Rep 1:99-114

21. Moore GE, Bross ID, Ausmans R, Nadler S, Jones R Jr, Slack N, Rimm AA (1968) Effects of mitomycin C in 346 patients with advanced cancer. Eastern Clinical Drug Evaluation Program. Cancer Chemother Rep 52:675-684

22. Kano Y, Suzuki K, Akutsu M, Suda K, Inoue Y, Yoshida M, Sakamoto S, Miura Y (1992) Effects of CPT-11 in combination with other anti-cancer agents in culture. Int J Cancer 50:604-610

23. Sawada N, Ishikawa T, Fukase Y, Nishida M, Yoshikubo T, Ishitsuka H (1998) Induction of thymidine phosphrylase activity and enhancement of capecitabine efficacy by taxol/taxotere in human cancer xenografts. Clin Cancer Res 4:1013-1019

24. Franchi F, Barone C, Seminara P, Codacci-Pisanelli G, CodacciPisanelli M, Ferri GM, Garufi C, Grieco A, Pagani V (1991) 5-Fluorouracil (FU) and mitomycin C(MMC) in the management of colorectal carcinoma. Part II. In vitro activity of the two drugs in short-term tumor cultures. Med Oncol Tumor Pharmacother 8:75-78

25. Pan G, O'Rourke K, Chinnaiyan AM, Gentz R, Ebner R, Ni J, Dixit VM (1997) The receptor for the cytotoxic ligand TRAIL. Science 276:111-113

26. Pan G, Ni J, Wei YF, Yu G, Gentz R, Dixit VM (1997) An antagonist decoy receptor and a death domain-containing receptor for TRAIL. Science 277:815-818

27. Schneider P, Thome M, Burns K, Bodmer JL, Hofmann K, Kataoka T, Holler N, Tschopp J (1997) TRAIL receptors 1 DR4 and 2 DR5 signal FADD-dependent apoptosis and activate NFkappaB. Immunity 7:831-836

28. Chaudhary PM, Eby M, Jasmin A, Bookwalter A, Murray J, Hood L (1997) Death receptor 5, a new member of the TNFR family, and DR4 induce FADD-dependent apoptosis and activate the NF-kappaB pathway. Immunity 7:821-830

29. Walczak H, Degli-Esposti MA, Johnson RS, Smolak PJ, Waugh JY, Boiani N, Timour MS, Gerhart MJ, Schooley KA, Smith CA, Goodwin RG, Rauch CT (1997) TRAIL-R2: a novel apoptosismediating receptor for TRAIL. EMBO J 16:5386-5397

30. Wu GS, Burns TF, McDonald ER 3rd, Jiang W, Meng R, Krantz ID, Kao G, Gan DD, Zhou JY, Muschel R, Hamilton SR, Spinner NB, Markowitz S, Wu G, el-Deiry WS (1997) KILLER/DR5 is a DNA damage-inducible p53-regulated death receptor gene. Nat Genet 17:141-143

31. Wiley SR, Schooley K, Smolak PJ, Din WS, Huang CP, Nicholl JK, Sutherland GR, Smith TD, Rauch C, Smith CA, Goodwin RG (1995) Identification and characterization of a new member of the TNF family that induces apoptosis. Immunity 3:673-682

32. Griffith TS, Lynch DH (1998) TRAIL: a molecule with multiple receptors and control mechanisms. Curr Opin Immunol 10:559-563

33. Lacour S, Hammann A, Wotawa A, Corcos L, Solary E, Dimanche-Boitrel MT (2001) Anticancer agents sensitize tumor cells to tumor necrosis factor-related apoptosis-inducing ligandmediated caspase activation and apoptosis. Cancer Res 61:1645-1651

34. Keane MM, Ettenberg SA, Nau MM, Russell EK, Lipkowitz S (1999) Chemotherapy augments TRAIL-induced apoptosis in breast cell lines. Cancer Res 59:734-741 
35. Nagane M, Pan G, Weddle JJ, Dixit VM, Cavenee WK, Huang HJ (2000) Increased death receptor 5 expression by chemotherapeutic agents in human gliomas causes synergistic cytotoxicity with tumor necrosis factor-related apoptosis-inducing ligand in vitro and in vivo. Cancer Res 60:847-853

36. Gibson SB, Oyer R, Spalding AC, Anderson SM, Johnson GL (2000) Increased expression of death receptors 4 and 5 synergizes the apoptosis response to combined treatment with etoposide and TRAIL. Mol Cell Biol 20:205-212

37. Singh TR, Shankar S, Chen X, Asim M, Srivastava RK (2003) Synergistic interactions of chemotherapeutic drugs and tumor necrosis factorrelated apoptosis-inducing ligand/Apo-2 ligand on apoptosis and on regression of breast carcinoma in vivo. Cancer Res 63:5390-5400

38. Asakuma J, Sumitomo M, Asano T, Hayakawa M (2003) Selective Akt inactivation and tumor necrosis actor-related apoptosis-inducing ligand sensitization of renal cancer cells by low concentrations of paclitaxel. Cancer Res 63:1365-1370

39. Stuckey DW, Shah K (2013) TRAIL on trial: preclinical advances in cancer therapy. Trends Mol Med 19:685-694

40. Yoo J, Kim HR, Lee YJ (2006) Hyperthermia enhances tumour necrosis factor-related apoptosis-inducing ligand (TRAIL)induced apoptosis in human cancer cells. Int J Hyperthermia 22:713-728

41. Yoo J, Lee YJ (2008) Effect of hyperthermia and chemotherapeutic agents on TRAIL-induced cell death in human colon cancer cells. J Cell Biochem 103:98-109

42. Song X, Kim HC, Kim SY, Basse P, Park BH, Lee BC, Lee YJ (2012) Hyperthermia-enhanced TRAIL-and mapatumumabinduced apoptotic death is mediated through mitochondria in human colon cancer cells. J Cell Biochem 113:1547-1558

43. Song X, Kim SY, Lee YJ (2012) The role of Bcl-xL in synergistic induction of apoptosis by mapatumumab and oxaliplatin in combination with hyperthermia on human colon cancer. Mol Cancer Res 10:1567-1579

44. Dewey WC, Sapareto SA, Betten DA (1978) Hyperthermic radiosensitization of synchronous Chinese hamster cells: relationship between lethality and chromosomal aberrations. Radiat Res 76:48-59

45. Holahan EV, Highfield DP, Holahan PK, Dewey WC (1984) Hyperthermic killing and hyperthermic radiosensitization in Chinese hamster ovary cells: effects of $\mathrm{pH}$ and thermal tolerance. Radiat Res 97:108-131

46. Kampinga HH, Dikomey E (2001) Hyperthermic radiosensitization: mode of action and clinical relevance. Int $\mathrm{J}$ Radiat Biol 77:399-408

47. Haas GP, Klugo RC, Hetzel FW, Barton EE, Cerny JC (1984) The synergistic effect of hyperthermia and chemotherapy on murine transitional cell carcinoma. J Urol 132:828-833

48. Herman TS, Sweets CC, White DM, Gerner EW (1982) Effect of heating on lethality due to hyperthermia and selected chemotherapeutic drugs. J Natl Cancer Inst 68:487-491

49. Ko SH, Ueno T, Yoshimoto Y, Yoo JS, Abdel-Wahab OI, Abdel-Wahab Z, Chu E, Pruitt SK, Friedman HS, Dewhirst MW, Tyler DS (2006) Optimizing a novel regional chemotherapeutic agent against melanoma: hyperthermia-induced enhancement of temozolomide cytotoxicity. Clin Cancer Res 12:289-297

50. Song X, Kim SY, Zhou Z, Lagasse E, Kwon YT, Lee YJ (2013) Hyperthermia enhances mapatumumab-induced apoptotic death through ubiquitin-mediated degradation of cellular FLIP(long) in human colon cancer cells. Cell Death Dis 4:e577

51. Krueger A, Schmitz I, Baumann S, Krammer PH, Kirchhoff S (2001) Cellular FLICE-inhibitory protein splice variants inhibit different steps of caspase-8 activation at the CD95 death-inducing signaling complex. J Biol Chem 276:20633-20640
52. Kober AM, Legewie S, Pforr C, Fricker N, Eils R, Krammer PH, Lavrik IN (2011) Caspase-8 activity has an essential role in CD95/Fas-mediated MAPK activation. Cell Death Dis 2:e212

53. Parrish AB, Freel CD, Kornbluth S (2013) Cellular mechanisms controlling caspase activation and function. Cold Spring Harb Perspect Biol 5:a008672

54. Xiaofeng W, Yukai H, Louis DF, Kam MH, Leaf H (2001) Regression of human mammary adenocarcinoma by systemic administration of a recombinant gene encoding the hFlex TRAIL fusion protein. Mol Ther 3:368-374

55. Shah K, Tung CH, Yang K, Weissleder R, Breakefield XO (2004) Inducible release of TRAIL fusion proteins from a proapoptotic form for tumor therapy. Cancer Res 64:3236-3242

56. Hardy S, Kitamura M, Harris-Stansil T, Dai U, Phipps ML (1997) Construction of adenovirus vectors through Cre-lox recombination. J Virol 71:1842-1849

57. Kim SY, Song X, Zhang L, Bartlett DL, Lee YJ (2014) Role of Bcl-xL/Beclin-1 in interplay between apoptosis and autophagy in oxaliplatin and bortezomib-induced cell death. Biochem Pharmacol 88:178-188

58. Wirawan E, Vande Walle L, Kersse K, Cornelis S, Claerhout S, Vanoverberghe I, Roelandt R, De Rycke R, Verspurten J, Declercq W, Agostinis P, Vanden Berghe T, Lippens S, Vandenabeele $P$ (2010) Caspase-mediated cleavage of Beclin-1 inactivates Beclin-1-induced autophagy and enhances apoptosis by promoting the release of proapoptotic factors from mitochondria. Cell Death Dis 1:e18

59. Li H, Wang P, Sun Q, Ding WX, Yin XM, Sobol RW, Stolz DB, Yu J, Zhang L (2011) Following cytochrome c release, autophagy is inhibited during chemotherapy-induced apoptosis by caspase 8-mediated cleavage of Beclin 1. Cancer Res 71:3625-3634

60. Itakura E, Kishi C, Inoue K, Mizushima N (2008) Beclin 1 forms two distinct phosphatidylinositol 3-kinase complexes with mammalian Atg14 and UVRAG. Mol Biol Cell 19:5360-5372

61. Iijima K, Ohara M, Seki R, Tauchi H (2008) Dancing on damaged chromatin: functions of ATM and the RAD50/MRE11/ NBS1 complex in cellular responses to DNA damage. J Radiat Res 49:451-464

62. Hayashi N, Kobayashi M, Shamma A, Morimura Y, Takahashi C, Yamamoto K (2013) Regulatory interaction between NBS1 and DNMT1 responding to DNA damage. J Biochem 154:429-435

63. Kharbanda S, Ren R, Pandey P, Shafman TD, Feller SM, Weichselbaum RR, Kufe DW (1995) Activation of the c-Abl tyrosine kinase in the stress response to DNA-damaging agents. Nature 376:785-788

64. Price BD, Hughes-Davies L, Park SJ (1995) Cdk2 kinase phosphorylates serine 315 of human p53 in vitro. Oncogene 11:73-80

65. Milne DM, Palmer RH, Campbell DG, Meek DW (1992) Phosphorylation of the p53 tumour-suppressor protein at three N-terminal sites by a novel casein kinase I-like enzyme. Oncogene 7:1361-1369

66. Hall SR, Campbell LE, Meek DW (1996) Phosphorylation of p53 at the casein kinase II site selectively regulates p53-dependent transcriptional repression but not transactivation. Nucleic Acids Res 24:1119-1126

67. Baudier J, Delphin C, Grunwald D, Khochbin S, Lawrence JJ (1992) Characterization of the tumor suppressor protein p53 as a protein kinase $\mathrm{C}$ substrate and a S100b-binding protein. Proc Natl Acad Sci USA 89:11627-11631

68. Milne DM, Campbell DG, Caudwell FB, Meek DW (1994) Phosphorylation of the tumor suppressor protein p53 by mitogenactivated protein kinases. J Biol Chem 269:9253-9260

69. Milne DM, Campbell LE, Campbell DG, Meek DW (1995) p53 is phosphorylated in vitro and in vivo by an ultraviolet radiationinduced protein kinase characteristic of the c-Jun kinase, JNK1. J Biol Chem 270:5511-5518 
70. Jamal S, Ziff EB (1995) Raf phosphorylates p53 in vitro and potentiates p53-dependent transcriptional transactivation in vivo. Oncogene 10:2095-2101

71. Shieh SY, Ikeda M, Taya Y, Prives C (1997) DNA damageinduced phosphorylation of p53 alleviates inhibition by MDM2. Cell 91:325-334

72. Tibbetts RS, Brumbaugh KM, Williams JM, Sarkaria JN, Cliby WA, Shieh SY, Taya Y, Prives C, Abraham RT (1999) A role for ATR in the DNA damage-induced phosphorylation of p53. Genes Dev 13:152-157

73. Alcala MA, Park K, Yoo J, Lee DH, Park BH, Lee BC, Bartlett DL, Lee YJ (2010) Effect of hyperthermia in combination with TRAIL on the JNK-Bim signal transduction pathway and growth of xenograft tumors. J Cell Biochem 110:1073-1081

74. Sun BK, Kim JH, Nguyen HN, Oh S, Kim SY, Choi HJ, Lee YJ, Song JJ (2011) MEKK1/MEKK4 are responsible for TRAILinduced JNK/p38 phosphorylation. Oncol Rep 25:537-544
75. Song X, Kim SY, Lee YJ (2013) Evidence for two modes of synergistic induction of apoptosis by mapatumumab and oxaliplatin in combination with hyperthermia in human colon cancer cells. PLoS ONE 8:e73654

76. Ubersax JA, Ferrell JE Jr (2007) Mechanisms of specificity in protein phosphorylation. Nat Rev Mol Cell Biol 8:530-541

77. Basu A, Haldar S (2003) Identification of a novel Bcl-xL phosphorylation site regulating the sensitivity of taxol- or 2-methoxyestradiol-induced apoptosis. FEBS Lett 538:41-47

78. Kharbanda S, Saxena S, Yoshida K, Pandey P, Kaneki M, Wang Q, Cheng K, Chen YN, Campbell A, Sudha T, Yuan ZM, Narula J, Weichselbaum R, Nalin C, Kufe D (2000) Translocation of SAPK/JNK to mitochondria and interaction with $\mathrm{Bcl}-\mathrm{x}(\mathrm{L})$ in response to DNA damage. J Biol Chem 275:322-327

79. Wei Y, Pattingre S, Sinha S, Bassik M, Levine B (2008) JNK1mediated phosphorylation of Bcl-2 regulates starvation-induced autophagy. Mol Cell 30:678-688 